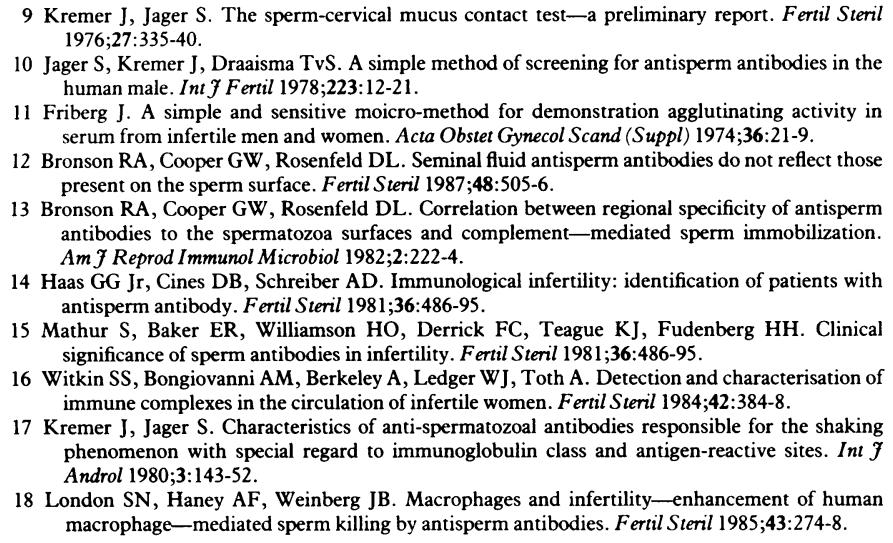

9 Kremer J, Jager S. The sperm-cervical mucus contact test-a preliminary report. Fertil Steril 1976;27:335-40

10 Jager S, Kremer J, Draaisma TvS. A simple method of screening for antisperm antibodies in the human male. Int f Fertil 1978;223:12-21.

11 Friberg J. A simple and sensitive moicro-method for demonstration agglutinating activity in serum from infertile men and women. Acta Obstet Gynecol Scand (Suppl) 1974;36:21-9.

12 Bronson RA, Cooper GW, Rosenfeld DL. Seminal fluid antisperm antibodies do not reflect those present on the sperm surface. Fertil Steril 1987;48:505-6.

13 Bronson RA, Cooper GW, Rosenfeld DL. Correlation between regional specificity of antisperm antibodies to the spermatozoa surfaces and complement-mediated sperm immobilization. Am 7 Reprod Immunol Microbiol 1982;2:222-4.

14 Haas GG Jr, Cines DB, Schreiber AD. Immunological infertility: identification of patients with antisperm antibody. Fertil Steril 1981;36:486-95.

15 Mathur S, Baker ER, Williamson HO, Derrick FC, Teague KJ, Fudenberg HH. Clinical significance of sperm antibodies in infertility. Fertil Steril 1981;36:486-95.

16 Witkin SS, Bongiovanni AM, Berkeley A, Ledger WJ, Toth A. Detection and characterisation of immune complexes in the circulation of infertile women. Fertil Steril 1984;42:384-8.

17 Kremer J, Jager S. Characteristics of anti-spermatozoal antibodies responsible for the shaking phenomenon with special regard to immunoglobulin class and antigen-reactive sites. Int $\mathcal{J}$ Androl 1980;3:143-52.

18 London SN, Haney AF, Weinberg JB. Macrophages and infertility-enhancement of human macrophage-mediated sperm killing by antisperm antibodies. Fertil Steril 1985;43:274-8.

19 Bronson R, Cooper G, Rosenfeld DL. Complement mediated effects of sperm head-directed human antibodies on the ability of human spermatozoa to penetrate zona-free hamster eggs. Fertil Steril 1983;40:91-9.

20 Mandelbraum SL, Diamond MP, de Cherney AH. Relationship of antisperm antibodies to oocyte fertilization and cleavage in in vitro fertilisation. Fertil Steril 1987;47:644-51.

21 Shulman S, Harlin B, David P, Reyniak JV. Immune infertility and new approaches to treatment. Fertil Steril 1978;29:309-13.

22 Hendry WF, Stedronska J, Paslaw J, Hughes L. The results of intermittent high dose steroid therapy for male infertility due to antisperm antibodies. Fertil Steril 1981;36:351-5.

23 Hargreave TB, Ecton R. Treatment with intermittent high-dose methylprednisolone or intermittent betamethasone for antisperm antibodies. Fertil Steril 1982;38:586-90.

24 De Almeida M, Feneux D, Rigaud C, Jouannet P. Steroid therapy for male infertility associated with antisperm antibodies. Results of a small randomized clinical trial. Int $\mathcal{f}$ Androl 1985;8: $111-7$.

25 Hendry WF. Treatment of antisperm antibodies. In: Hargreave TB, ed. Male Infertility. Berlin: Springer Verlag, 1983:280-96.

26 Kremer J, Jager S, Kiuken J. Treatment of infertility caused by antisperm antibodies. Int $\mathcal{Y}$ Fertil 1978;23:270-6.

27 Allen NC, Herbert CM, Maxson WS, Rogers BJ, Diamond MP, Wentz AC. Intrauterine insemination: a critical review. Fertil Steril 1985;44:569-80.

28 Yovich JL, Stanger JD, Kay D, Boettcher B. In vitro fertilisation of oocytes from women with serum antisperm antibodies. Lancet 1984;i:369-70.

\title{
How does smoking harm the duodenum?
}

The relation between smoking and duodenal ulcer has often been examined, yet some reviewers take a sceptical view on whether smoking is important in duodenal ulcers ${ }^{1}$ while others state that patients with duodenal ulcers should stop smoking. ${ }^{2}$ The controversy has continued until recently, ${ }^{3}$ but the best recent evidence is that smoking slows the healing of duodenal ulcers and encourages recurrence. ${ }^{45}$ What is not clear is why smoking has these effects.

Contradictory answers have been given to the question of whether smoking increases gastric acid secretion. Intravenous nicotine does not increase acid secretion, ${ }^{6}$ and patients with duodenal ulcers who smoke do not show any increase in basal secretion of acid or pepsin or in serum concentrations of pepsinogen I while smoking. ${ }^{7}$ But chronic smoking is associated with significantly higher acid secretion after pentagastrin stimulation and increased serum concentrations of pepsinogen I. ${ }^{7}$ Maximal acid output was increased in male but not female smokers with duodenal ulcers, ${ }^{8}$ but after controlling for variables such as height and age the effect of smoking on acid secretion was no greater in patients with duodenal ulcers than in normal subjects. ' Studies of the effect of smoking on duodenal $\mathrm{pH}$ have also produced conflicting results. ${ }^{1011}$

Other possible explanations of how smoking affects duodenal ulcers have also come to grief. Neither smoking nor intravenous nicotine has been shown to affect the production of gastric mucus, ${ }^{12}$ and in the duodenum both basal bicarbonate secretion and secretion after acid stimulation are unaltered by smoking. ${ }^{13}$ The evidence that smoking increases bile reflux into the stomach from the duodenum ${ }^{14}$ may explain the effects of smoking on gastric ulcer but not duodenal ulcer. ${ }^{2}$

Smoking has, however, been reported to reduce the amount of prostaglandin $E_{2}$ in gastric juice ${ }^{15}$ and to inhibit prostaglandin synthesis in gastric mucosa. ${ }^{16}$ These effects seem to be rapidly reversible, which means that if prostaglandin deficiency explains the effects of smoking on peptic ulcer then stopping smoking would be quickly beneficial. ${ }^{16}$ Unfortunately, this hypothesis probably does not explain the effects of smoking on duodenal ulcer because prostaglandin production by duodenal mucosa seems to be unaffected by smoking.

Another way of investigating the effects of smoking on duodenal ulcers is to look at how smoking alters treatment.
Smoking is thought to reduce the antisecretory activity of $\mathrm{H}_{2}$ receptor antagonists ${ }^{17}$ and to decrease their effects on nocturnal acidity - possibly because of reduced plasma concentrations of the drugs, which might be caused by increased gastric emptying. ${ }^{18}$ Others, however, have found that smoking does not interfere significantly with the action of $\mathrm{H}_{2}$ receptor antagonists. ${ }^{19}$

Although smoking might hamper treatment with antisecretory agents, it does not interfere with drugs that enhance mucosal defences. Thus healing rates and lengths of remission were significantly greater in smokers with duodenal ulcers treated with sucralfate than in those treated with cimetidine ${ }^{20}$ Smoking caused more frequent and earlier relapses in patients treated with ranitidine but had no effect on patients treated with colloidal bismuth. ${ }^{21}$ Similarly, the ulcer healing properties of misoprostol, a derivative of prostaglandin $E_{1}$, were unaffected by cigarette smoking, ${ }^{4}$ and the same has been claimed for enprostil, a derivative of prostaglandin $\mathrm{E}_{2} \cdot{ }^{22}$

It thus seems that the adverse effects of smoking on duodenal ulcers are overcome either by prostaglandin analogues or by drugs such as sucralfate and colloidal bismuth that stimulate endogenous prostaglandin production. ${ }^{23}$ This fits with the evidence that smoking reduces prostaglandin synthesis in gastric mucosa if not in duodenal mucosa. It may be that in smokers with duodenal ulcers active smoking impairs prostaglandin release in the duodenum in response to an acid load, although basal prostaglandin generation is unchanged.

This is speculation, and more work must be done to elucidate how smoking harms the duodenum. There is no doubt, however, that patients who want their duodenal ulcers to heal and stay healed should stop smoking.

Gastroenterologist,

M GUSLANDI

Institute of Internal Medicine,

University of Milan,

20122 Milan,

Italy

1 Wormsley KG. Smoking and duodenal ulcer. Gastroenterology 1978;75:139-42.

2 McCarthy DM. Smoking and ulcers-time to quit. $N$ Engl f Med 1984;311:726-8.

3 Barakat MH, Menon KM, Badawi AR. Cigarette smoking and duodenal ulcer healing. Digestion 1984;29:85-90.

4 Bauerfeind P, Popien J, Traber M, et al. Clinical perspectives of drugs inhibiting acid secretion: histamine $\mathrm{H}_{2}$ antagonists. Scand f Gastroenterol 1986;21(suppl 125):42-8. 
5 Lam SK, Lau WY, Choi TK, et al. Prostaglandin E 1(misoprostol) overcomes the adverse effect of chronic cigarette smoking on duodenal ulcer healing. $D i g$ Dis $S c i$ 1986;31:68-74S.

6 Sonnenberg A, Husmert N. Effect of nicotine on gastric mucosal blood flow and acid secretion. Gut 1982;23:532-5.

7 Parente F, Lazzaroni M, Sangaletti O, Baroni S, Bianchi Porro G. Cigarette smoking, gastric acid secretion and serum pepsinigen 1 concentrations in duodenal ulcer patients. Gut 1985;26: $1327-32$.

8 Whitfield PF, Hobsley M. Maximal gastric secretion in smokers and non-smokers with duodenal ulcer. Brf S Surg 1985;72:955-7.

9 Whitfield PF, Hobsley M. Comparison of maximal gastric secretion in smokers and non-smokers with and without duodenal ulcer. Gut 1987;28:557-60.

10 Murthy SNS, Dinoso VP, Clearfield HR, Chey WV. Serial pH changes in the duodenal bulb during smoking. Gastroenterology 1978;75:1-4.

11 McCloy RF, Greenberg GR, Baron JH. Duodenal pH in health and duodenal ulcer disease: effect of a meal, Coca-Cola, smoking and cimetidine. Gut 1984;25:386-92.

12 Rack J, Sonnenberg $A$. The influence of smoking and intravenous nicotine on gastric mucus. Hepatogastroenterology 1983;30:258-60.

13 Thomas FJ, Hogan DL, Koss MA, Sackman JW, Algazi M, Isenberg JI. The effect of smoking on basal and acid-stimulated duodenal bicarbonate secretion in humans. Gastroenterology 1986; 90:1663.

14 Muller-Lissner SA. Bile reflux is increased in cigarette smokers. Gastroenterology 1986;90:1205-9.
15 McCready DR, Clark L, Cohen MM. Cigarette smoking reduces human gastric luminal prostaglandin $\mathrm{E}_{2}$. Gut 1985;26:1192-6.

16 Quimby GF, Bonnice CA, Burnstein SH, Eastwood GL. Active smoking depresses prostaglandin synthesis in human gastric mucosa. Ann Intern Med 1986;104:616-9.

17 Boyd EJS, Wilson JA, Wormsley KG. Smoking impairs therapeutic gastric inhibition. Lancet 1983;i:95-7.

18 Boyd EJS, Johnston DA, Wormsley KG, Jenner WN, Salanson W. The effects of cigarette smoking on plasma concentrations of gastric antisecretory drugs. Alimentary Pharmacology and Therapeutics 1987; 1:57-65.

19 Bauerfeind $\mathrm{P}$, Cilluffo T, Fimmel CJ, et al. Does smoking interfere with the effect of histamine $\mathrm{H}_{2}$-receptor antagonists on intragastric acidity in man? Gut 1987;28:549-56.

20 Lam SK, Hui WM, Lau WY, et al. Sucralfate overcomes adverse effect of cigarette smoking on duodenal ulcer healing and prolongs subsequent remission. Gastroenterology 1987;92: 1193-1201.

21 Lee FI, Samloff IM, Hardman M. Comparison of tripotassium di-citrato bismuthate tablets with ranitidine in healing and relapse of duodenal ulcer. Lancet 1985; i:1299-301.

22 Lam SK. Prostaglandins for duodenal ulcer and gastric ulcer. Fournal of Gastroenterology and Hepatology 1986;1:471-81.

23 Konturek SJ, Radecki T, Piastucki I, Brzozowski T, Drozdowicz D. Gastrocytoprotection by colloidal bismuth subcitrate (De-Nol) and sucralfate. Role of endogenous prostaglandins.
Gut 1987;28:201-5.

\section{Prevention in practice: a new initiative}

There is increasing agreement that general practice is the best channel through which to increase preventive care. The government made it clear in its recent white paper on primary care that it wanted general practitioners to undertake more preventive care, and now for the first time the BMA is mounting a preventive campaign focused on the general practitioner. But what should be the priorities for general practitioners who want to practise more prevention?

There is no shortage of candidates-for instance, cervical screening, detection of risk factors for coronary artery disease, immunisation, contraception, breast screening, paediatric surveillance, and screening of the elderly. In 1988 all these will compete, along with routine clinical care, for general practitioners' limited time. In this climate it is right that the BMA should remind us of the World Health Organisation's priority in preventive care-smoking. On 27 January every general practitioner member of the BMA will receive along with their copy of $B M A$ News Review a booklet on how to help patients stop smoking. This booklet illustrates dramatically the continuing death toll from the cigarette (the equivalent in Britain of a full jumbo jet crashing each day and killing all on board), setting out practical suggestions that can be put to patients. It urges that as a minimum all doctors should record their patients' smoking history and, if necessary, advise them to stop smoking and offer them the booklet. The project, which will last three years and be evaluated, is based on the WHO's 50 page manual for primary care on smoking and will be funded by the Imperial Cancer Research Fund. The BMA initiative arose out of a meeting of the national medical associations in Europe in 1986, when it was agreed that smoking was the most important issue in preventive care.

In Britain Russell and others showed in 1979 that after simple advice to stop smoking reinforced by a leaflet and warning of follow up 5\% of general practitioners' patients were not smoking a year later. ${ }^{1}$ More recent studies in primary health care have shown even better results, with one year non-smoking rates of $9 \%,{ }^{2} 10 \%,{ }^{3} 17 \%,{ }^{4} 19 \%,{ }^{5}$ and $27 \% .{ }^{6}$ Wallace has confirmed that most patients are concerned about smoking and welcome counselling and help, ${ }^{7}$ and the British Regional Heart Study, which is following 7735 middle aged men over eight years in general practice, has emphasised that smoking is a critical risk factor in cardiovascular disease. ${ }^{8}$ This study also makes the point that the counselling of smokers should start at the earliest possible date as risk is related to the length of time a patient has smoked.

Will general practitioners participate? This is where more research is required. What makes one general practitioner take an active part in prevention and another ignore it? The figures seem to point to doctors being better at changing their own behaviour than getting their patients to do the same. In Britain only $16 \%$ of the professional classes now smoke, for example, though $49 \%$ of men and $36 \%$ of women in the manual trades still do so. ${ }^{9}$ Equally worrying is the fact that the young continue to become smokers. In the 16-19 year old group $29 \%$ of men and $32 \%$ of women are regular smokers. Even in the 11-15 year old group girls outnumber boys at $12 \%$ to $7 \% .^{10}$

Perhaps general practitioners would be more motivated to contribute to this BMA campaign if they were given increased support from other sources. No Smoking Day (9 March) is a good time for the media to help, while the coming budget offers an opportunity for the government to give its support by increasing considerably the tax on cigarettes; the government should also reconsider its policy of allowing the tobacco industry to sponsor sport. Could prevention in practice become in Britain a national activity in which the priorities are agreed and general practitioners, professional organisations, patients, parents, employers, voluntary bodies, the media, and the government all play an enthusiastic and active part?

Part-time Senior Lecturer in General Practice,

Royal Free Hospital School of Medicine,

London NW3 2PF

1 Russell MAH, Wilson C, Taylor C, Baker CD. Effects of general practitioners advice against smoking. Br Med J 1979;ii:231-5.

2 Russell MAH, Merriman R, Stapleton J, Taylor W. Effects of nicotine chewing gum as an adjunct to general practitioners' advice against smoking. $\mathrm{Br} \mathrm{Med}$ f 1983;287:1782-5.

3 Jamrozik K, Fowler G, Vessey M, Wald N. Placebo controlled trial of nicotine chewing gum in general practice. BrMed f 1984;289:794-7.

4 Marshall A, Raw M. Nicotine chewing gum in general practice: effect of follow up appointments. BrMed F 1985;290:1397-8.

5 Richmond RL, Austin A, Webster IW. Three year evaluation of a programme by general practitioners to help patients to stop smoking. BrMed f 1986;292:803-6.

6 Fagerstrom K-O. Effects of nicotine chewing gum and follow-up appointments in physician based smoking cessation. Prev Med 1984;13:517-27.

7 Wallace PG, Brennan PJ, Haines AP. Are general practitioners doing enough to promote healthy lifestyle? Findings of the Medical Research Council's general practice research framework study on lifestyle and health. BrMed $\mathcal{F}$ 1987;294:940-2.

8 Cook DG, Shaper AG, Pocock SJ, Kussick SJ. Giving up smoking and the risk of heart attacks: a report from the British Regional Heart Study. Lancet 1986;ii:1376-80.

9 Office of Population Censuses and Surveys. General household survey. London: HMSO, 1985. (OPCS Monitor. GHS 85/2.)

10 Office of Population Censuses and Surveys. Smoking among schoolchildren in 1986. London: HMSO, 1987. 